\title{
Limatula chilensis sp. nov. A new Limidae (Mollusca: Bivalvia) from northern Chile
}

\author{
Limatula chilensis sp. nov. Un nuevo Limidae (Mollusca: Bivalvia) en el norte de Chile
}

\section{Carla Adriana Campusanoํㅜ, Paula Mariela Ruz ${ }^{1}$ and Marcelo Enrique Oliva1}

\begin{abstract}
${ }^{1}$ Instituto de Investigaciones Oceanológicas, Facultad de Recursos del Mar, Universidad de Antofagasta, P.O. Box 170, Antofagasta, Chile. meoliva@uantof.cl
\end{abstract}

\begin{abstract}
Resumen.- Limatula chilensis sp. nov. se describe en base a la morfología de la concha y tejidos blandos. Los especímenes estudiados se obtuvieron periódicamente entre junio de 2008 y enero de 2009 desde fondos blandos someros submareales en Punta Coloso, norte de Chile, a profundidades entre 22 y $33 \mathrm{~m}$. La morfología de la concha es diferente a la de las 4 especies de Limatula descritas para las costas del Pacífico de Sudamerica y Península Antártica (5-65오). Las características más evidentes de L. chilensis fueron el tamaño 3,50 mm (rango 2,36-4,42, DE $\pm 0,60, \mathrm{n}=34$ ), número de costillas radiales 16-21 (moda = $20, \mathrm{DE}=1,69, \mathrm{n}=8$ ) y una fuerte oblicuidad de la concha. L. chilensis es la única especie conocida del género, para las costas del norte de Chile.
\end{abstract}

Palabras clave: Sistema de Corriente de Humboldt, Chile, nueva especie

\begin{abstract}
Limatula chilensis sp. nov. is described on the basis of shell morphology and soft tissue anatomy. Studied individuals were obtained periodically between June 2008 and January 2009 from sublittoral softsediments off Punta Coloso in northern Chile at depths of 22 to $33 \mathrm{~m}$. Shell morphology of the new species differs from the 4 described species of Limatula from the Pacific coast of South America and Antarctic Peninsula $\left(5^{\circ}-65^{\circ} \mathrm{S}\right)$. Main characteristics of L. chilensis include an average height of $3.50 \mathrm{~mm}$ (range 2.36 $4.42, \mathrm{SD} \pm 0.60, \mathrm{n}=34$ ), number of radial ribs $16-21$ (mode $=20, \mathrm{SD}=1.69, \mathrm{n}=8$ ) and greater shell obliqueness. L. chilensis is the only known species of the genus found off northern Chile.
\end{abstract}

Key words: Humboldt Current system, Chile, new species

\section{INTRODUCTION}

Limid bivalves, known as 'file clams', can be free-living organisms or can live attached to the substratum using byssal threads. Their distribution is worldwide at depths from 5 to 3,000 m (Fleming 1978, Dell 1990, Allen 2004).

Four species of Limatula have been recorded from the Pacific coast of South America, and three of them are distributed between $36^{\circ} \mathrm{S}$ and $66^{\circ} \mathrm{S}$ : L. pygmaea (Philippi, 1845) from the Magellan Strait and Beagle Channel (Linse 1999); L. ovalis Thiele, 1912, from the Antarctic Peninsula and L. hodgsoni (Smith, 1907) from the Magellan region (Page 2001, Page \& Linse 2002, Ríos et al. 2003), which constitutes the most northern record of the genus along the Chilean coast (Fig. 1). The fourth species, L. similaris (Dall, 1908), was described from the Gulf of Panamá and has been reported from northern Peru $\left(5^{\circ} \mathrm{S}\right)$ (Paredes et al. 1999, Ramirez et al. 2003). There are not information about Limatula in the northern Chilean coast and central south Peru.
Our research reports the discovery of Limatula chilensis sp. nov. based on descriptions of shell morphology and soft tissue anatomy. In addition, an external morphological comparison with Limatula spp. in the southeastern Pacific was done.

\section{Materials AND METHODS}

Sixty-three triplicate samples of sandy, soft-bottom benthic communities were obtained between June 2008 and January 2009 using a van Veen drag $\left(0.1 \mathrm{~m}^{2}\right)$ from 9

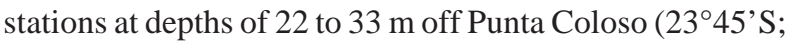
$70^{\circ} 28^{\prime} \mathrm{W}$ ) (Fig. 1). Maximum height and length of the valves were measured using a calliper ( $\pm 0.1 \mathrm{~mm}$ precision) and scanning electron microscope photographs, using a JSMT300 JEOL brand SEM, were used to describe valve morphology. Soft body tissues were stained with Gomori's Trichrome, then dissected and identified according to the characters given by Allen (2004). 


\section{DESCRIPTION}

Limatula chilensis sp. nov.

Type Locality: Live-taken Holotype (MNHNCL ${ }^{1}$ 6666) and paratypes (MNHNCL 6667- MNHNCL 6670) collected from soft bottom at 27-29 m depth. Punta Coloso Bahía San Jorge, northern Chile (234'ㅇ' 70²8’W) (Fig. 1).

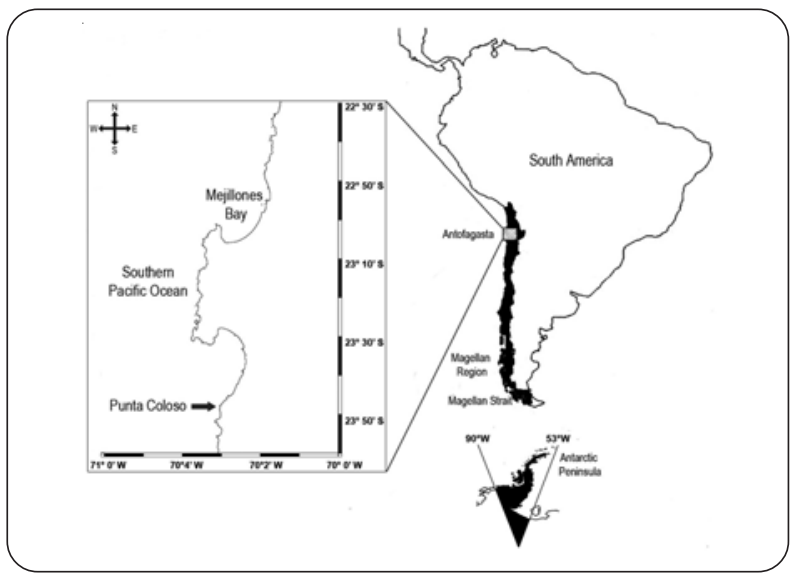

Figure 1. Study area and distribution of Limatula spp. at Chilean coast / Área de estudio y distribución de Limatula spp. en las costas de Chile
Shell Morphology: Description based on 34 individuals. The shell is small, thin, white, slightly translucent, inflated, oval, inequilateral, and opisthocline. The average height is $3.50 \mathrm{~mm}$ ( $\mathrm{SD} \pm 0.60 \mathrm{~mm}$, range 2.36 4.43), and the height/length ratio is 1.48 ( $\mathrm{SD} \pm 0.08 \mathrm{~mm}$, range 1.33-1.65). Shell sculpture is mostly ornamented with prominent radial ribs (ca., 16-21; mode = 20), lateral ribs are less prominent than central ribs, and narrow growth lines are more strongly marked on the ventral region, forming a slim reticulated shape. The ventral margin is crenulated by radial ribs pattern, lateral margins even more toward dorsal region. In the same specimen, the radial ribs are more pronounced on right valve (Fig. 2B) than on left one (Fig. 2A), and, as a consequence, the ventral margin is also more crenulated (Fig. 2B). Small ears are similar in size. Posterior subauricular sinus is more pronounced, anterior sinus is barely visible (Fig. 2A). Umbos are prominent and central to the hinge line (Fig. 2B and 2C). The hinge is without teeth, central and triangular ligament, extending laterally by dorsal margin of the shell (Fig. 2D).

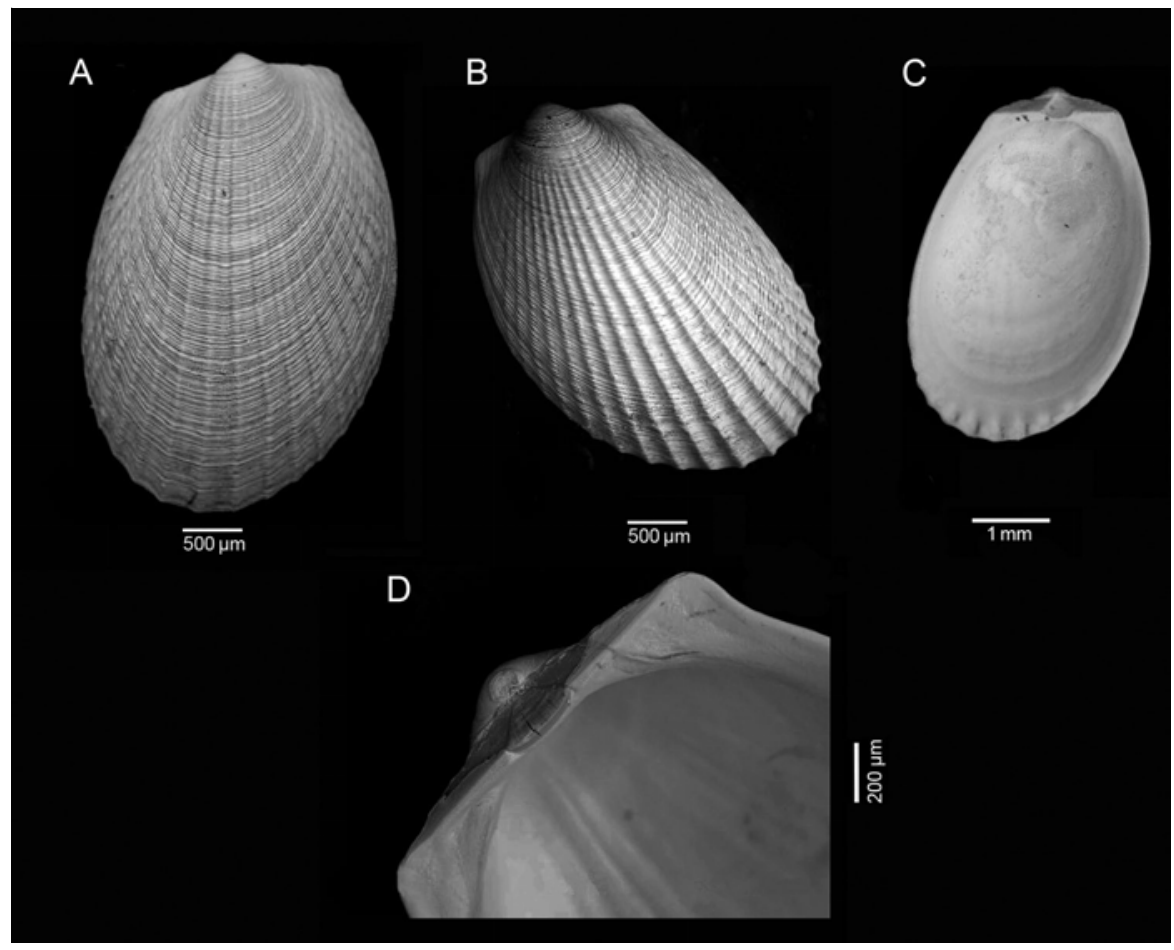

Figure 2. Scanning Electron Microscope photographs of Limatula chilensis sp. nov. shell: A) external view of left valve; B) external view of right valve; $C$ ) internal view of shell; and D) hinge plate / Microscopia electrónica de Barrido de Limatula chilensis sp. nov. concha: A) Vista externa de valva izquierda; B) Vista externa de valva derecha; $C$ ) vista interna de la concha y D) placa de articulación

${ }^{1}$ Abbreviations MNHNCL: Museo Nacional de Historia Natural Chile (National Museum of Natural History Chile) 
Anatomy: The mantle is thin and translucent, except at the margin. The developed sensory fold has approximately 27 tentacles that differ in size. Tentacles may extend over the shell margin, and ventral and posterior tentacles are more developed than tentacles located in the anterior region (Fig. 3). At the posterodorsal region near the fusion area of the mantle lobules exists two highly developed anal tentacles (one on each lobule), which extend to the middle area of the posterior adductor muscle. The gill axis runs from dorsal to the ventral region; gills are formed by wide demibranches with ascendant and descendent lamellas (Fig. 4). The digestive system starts at the mid-anterior region of the soft body tissue with the mouth surrounded by an upper and lower lip, continued by a short oesophagus, and a small dorsal stomach is covered by a large digestive gland. Details of the course of the gut through the digestive gland were not observed; the course through the visceral mass was partially observed. The ascending intestine is located at the posterior edge of the visceral mass. The hindgut extends over the mid-dorsal surface of the posterior adductor muscle. The anus is located at the mid-posterior surface of the same muscle. The foot is ventral and elongated with a visible byssal groove at the anterior part of the foot (Fig. 5).

\section{Discussion}

\section{TAXONOMIC REMARKS}

Unfortunately, all described species of Limatula from the Pacific coast of South America have been based on few (even 1) specimens and only shell have been described but not soft tissues. In addition no variability on morphometric measures was given.

Limatula chilensis sp. nov. shows differences in size and shell sculpture compared with Limatula spp. described from the Chilean coast (Fig. 6). L. chilensis shell size is the smallest of the published species from the Pacific coast of South America (Table 1) and most resembles $L$. similaris from Panamá and northern Perú. According to the original description of Dall (1908) length of shell is $4.7 \mathrm{~mm}$ but from a picture kindly send us by Valentich-Scott (Santa Barbara Museum of Natural History, (Fig. $6 \mathrm{D}$ ), length of the shell is more than $2.0 \mathrm{~cm}$. The general form of the shell is clearly different of the new species. In addition $L$. similaris has ears that are less developed, a more pronounced subauricular sinus, wider base of ligament shape, shorter hinge line, and less obliqueness of the shell. Table 1 shows the geographical

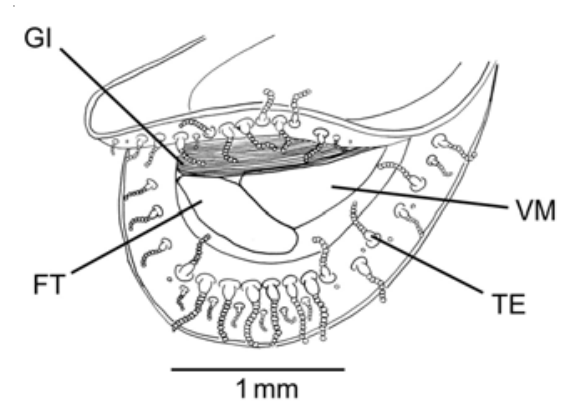

Figure 3. Limatula chilensis sp. nov. internal view of location of sensory tentacles. Abbreviation in annex / Limatula chilensis sp. nov. Vista interna de posición de tentáculos sensoriales. Abreviaciones en anexo

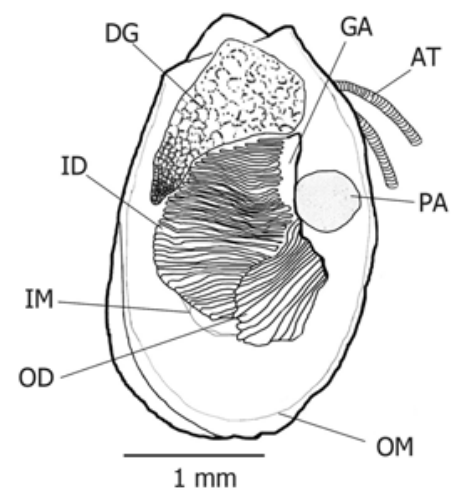

Figure 4. Limatula chilensis sp. nov. left side view of soft tissue. Abbreviation in annex / Limatula chilensis sp. nov. vista izquierda de tejidos blandos. Abreviaciones en anexo

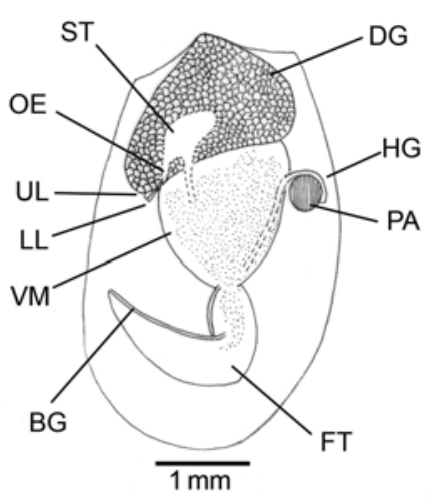

Figure 5. Limatula chilensis sp. nov. Mantle cavity and internal partial view of digestive system. Abbreviation in annex / Limatula chilensis sp. nov. Cavidad del manto y vista parcial del sistema digestivo. Abreviaciones en anexo 
Table 1. Main characteristic of described species of Limatula from the Pacific coast of South America / Características más importantes de las especies de Limatula descritas en las costas del Pacífico de Sud América

\begin{tabular}{|c|c|c|c|c|c|}
\hline & L. hodgsoni & L. pygmaea & L. ovalis & L. similaris & L. chilensis \\
\hline Height (mm) & $\begin{array}{c}10.0-15.5^{1} \\
>27^{2}\end{array}$ & $5.5^{3}$ & $\begin{array}{l}4.1^{2} \\
6.0^{5}\end{array}$ & 4.5 & 3.6 \\
\hline Length (mm) & 1.5 & 4.5 & $\begin{array}{l}5.0^{2} \\
4.3^{5}\end{array}$ & 2.7 & 2.4 \\
\hline Radial ribs & 32 & $\begin{array}{c}15^{4} \\
18-20^{2}\end{array}$ & $\sim 22$ & $\sim 16$ & $16-20$ \\
\hline $\begin{array}{l}\text { Ears size } \\
\text { Obliqueness }\end{array}$ & $\begin{array}{l}\text { anterior larger } \\
\text { ophistocline }\end{array}$ & $\begin{array}{l}\text { similars } \\
\text { acline }\end{array}$ & similars & similars & $\begin{array}{c}\text { similars } \\
\text { ophistocline }\end{array}$ \\
\hline Shape & subtriangular & subcircular & subcircular & oval & oval \\
\hline Distribution & $53^{\circ} \mathrm{S}$ & $53-55^{\circ} \mathrm{S}$ & $62^{\circ}-66^{\circ} \mathrm{S}$ & $5^{\circ} \mathrm{S}$ & $23^{\circ} \mathrm{S}$ \\
\hline Depth (m) & $9-732$ & $6-598$ & 665 & $55-106$ & $22-32$ \\
\hline
\end{tabular}

Original description (Smith 1907)

${ }^{2}$ According to Fleming (1978)

${ }^{3}$ Juvenile shell according to Fleming (1978)

${ }^{4}$ According to Dall (1908) original description

${ }^{5}$ According to Thiele (1912), original description

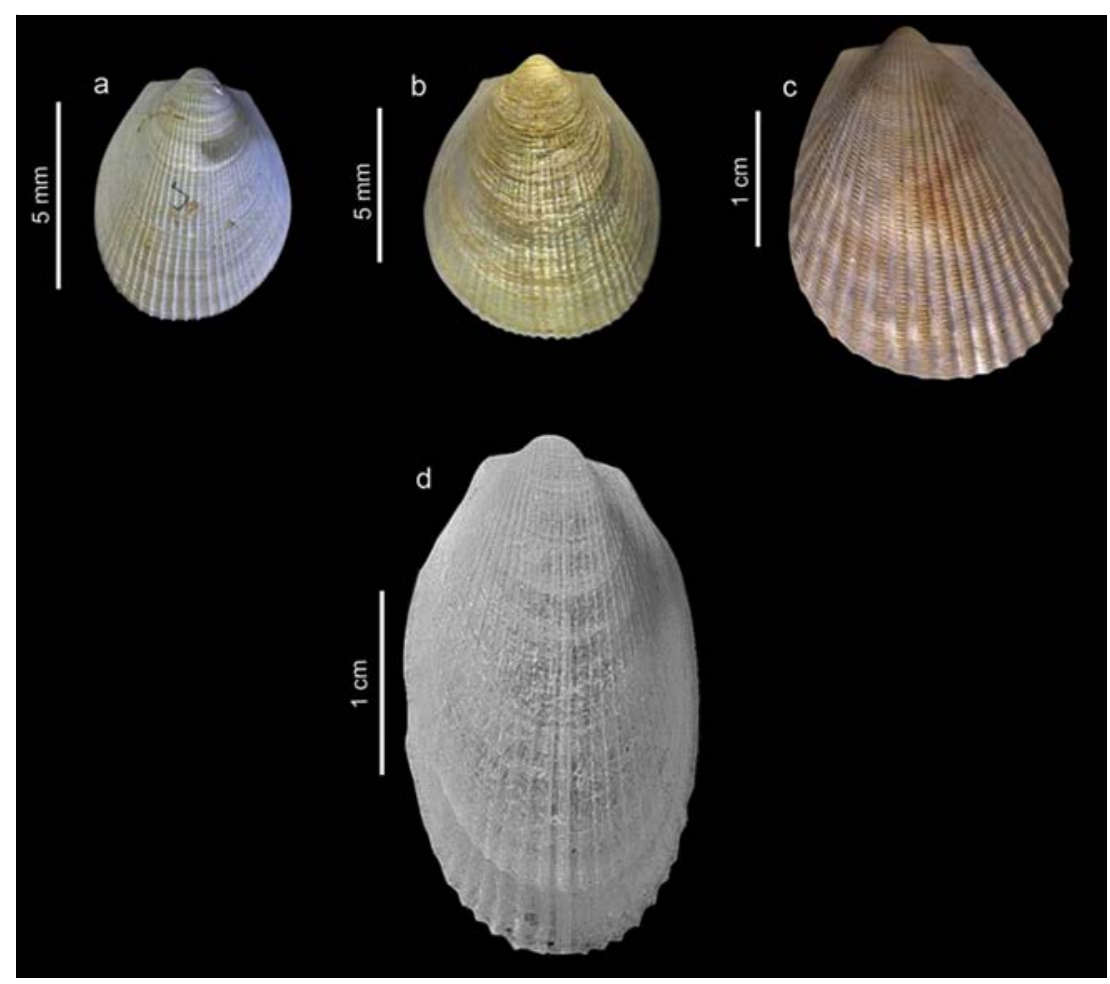

Figure 6. Species of Limatula described from the Pacific coast of South America. a) Limatula ovalis $^{1}$, b) Limatula pygmaea ${ }^{2}$, c) Limatula hodgsoni ${ }^{3}$, d) Limatula similaris 4 / Especies de Limatula descrita para las costas del Océano Pacífico de Sudamérica. a) Limatula ovalis ${ }^{1}$, b) Limatula pygmaea $^{2}$, c) Limatula hodgsoni ${ }^{3}$, d) Limatula similaris ${ }^{4}$

\footnotetext{
${ }^{1}$ USNM 896029, Smithsonian National Museum of Natural History, <http://invertebrates.si.edu/antiz/ taxon_view.cfm?taxon=7387>

${ }^{2}$ USNM 898433, Smithsonian National Museum of Natural History, <http://invertebrates.si.edu/antiz/ specimen_detail.cfm?irn=573068>

${ }^{3}$ Smithsonian National Museum of Natural History, <http://invertebrates.si.edu/antiz/specimen_detail.cfm?irn=571992> ${ }^{4}$ Photographs kindly send us by Paul Valentich-Scott, Santa Barbara Museum of Natural History. pvscott@sbnature2.org
} 
distribution and main taxonomic characters of Limatula spp. from the Pacific coast of South America (Chile-Peru). As stated in Table 1, the new species differ from $L$. hodgsoni in the ear size, obliqueness, number of radial ribs and shape; from L. pygmaea in obliqueness and shape and from $L$. ovalis in shape.

There are few studies considering the soft tissue anatomy in addition to shell morphology to describe species in the genus Limatula. Stuardo (1968) described, in an unpublished Doctoral Dissertation, the new species, Limatula araucana, using this methodology, unfortunately this species is nomenclatorically not valid. A similar study was conducted by Allen (2004), in which the internal and external morphology of nine species of Limatula from the Atlantic was analysed. Six of them were new species for the genus, showing differences among themselves in shell morphology, foot size, and number and size of sensorial tentacles.

\section{Distributional REMARKS}

Lee et al. (2008) conducted a comprehensive literature review of the free-living benthic fauna of the Chilean coast. They found 4,553 species of which 219 were bivalves, representing $4.8 \%$ of the species richness. Of these species, just five belonged to Limidae and one to the genus Limatula. Although other Limatula living at the southern Chilean coast and Antarctic Peninsula (Linse 1999, Page 2001, Page \& Linse 2002, Ríos et al. 2003) have been reported, they are still scarce. Laudien et al. (2007) described soft-bottom communities from Bahia Mejillones (ca., $70 \mathrm{~km}$ north of Punta Coloso) on the basis of a data set over the course of seven years (78 van Veen grab samples). The main finding included sparse bivalve fauna that represented $7 \%$ of the species richness in the area, and no Limidae were found in the study area. In addition, some descriptive studies of malacofauna off the central and northern Chilean coast did not report species of this genus (Ramorino 1968, Marincovich 1973, Guzmán et al. 1998). L. chilensis could be an example of a rare species, as it represents between $0.02-0.23 \%$ of all molluscs found in 63 samples obtained from the area. Similar results were obtained in the California Gulf, where Limatula similaris had a density of 0.013 ind $\mathrm{l}^{-1}$, corresponding to $1.3 \%$ of the samples in which the species was found (Zamorano et al. 2007). Zuschin \& Piller (1997) indicated that Lima lima was found in densities of 0.25 and 0.50 ind $\mathrm{m}^{-2}$, representing $4.69 \%$ and $6.67 \%$ of the total fauna obtained at stations where the individuals appeared. The low densities of these bivalves could be a good example of what have considered as hidden biodiversity.

\section{ACKNowledgments}

We thank Dr. José Stuardo (Universidad de Concepción, Chile), John A. Allen, and Fabrizio Scarabino (Museo Nacional de Historia Natural, Montevideo, Uruguay) for their help and early suggestions. Dr. Timothy Page and Dr. Carlos Rios (Universidad de Magallanes, Chile) provided useful references. Paul Valentich-Scott, Curator of Malacology of the Santa Barbara Museum of Natural History, is thanked for sending SEM photographs of Limatula similaris. This study was conducted in the framework of the Environmental Program of Minera Escondida Ltda. The authors thank two anonimous reviewers for valuble comments and suggestions.

\section{LITERATURE CITED}

Allen JA. 2004. The recent species of the genera Limatula and Limea (Bivalvia, Limacea) present in the Atlantic, with particular reference to those in deep water. Journal of Natural History 38: 2591-2653.

Dall WH. 1908. The Mollusca and Brachiopoda. Bulletin of the Museum of Comparative Zoology 43: 205-487.

Dell RK. 1990. Antarctic Mollusca with special reference to the fauna of the Ross Sea. Bulletin of the Royal Society of New Zealand 27: 1-311.

Fleming CA. 1978. The bivalve genus Limatula: a list of described species and a review of living and fossil species in the southwest Pacific. Journal of the Royal Society of New Zealand 8: 17-91.

Guzmán N, S Sáa \& L Ortlieb. 1998. Catálogo descriptivo de los moluscos litorales (Gastropoda y Pelecypoda) de la zona de Antofagasta, $23^{\circ} \mathrm{S}$ (Chile). Estudios Oceanológicos 17: 17-86.

Laudien J, ME Rojo, ME Oliva, WE Arntz \& S Thatje. 2007. Sublittoral soft bottom communities and diversity of Mejillones Bay in northern Chile (Humboldt Current upwelling system). Helgoland Marine Research 61: 103116.

Lee M, JC Castilla, M Fernández, M Clarke, C González, C Hermosilla, L Prado \& C Valdovinos. 2008. Freeliving benthic marine invertebrates in Chile. Revista Chilena de Historia Natural 81: 51-67.

Linse K. 1999. Mollusca of the Magellan region. A checklist of the species and their distribution. Scientia Marina 63: 399407.

Marincovich L. 1973. Intertidal mollusks of Iquique, Chile. Natural History Museum Los Angeles County, Science Bulletin 16: 1-49.

Page T. 2001. A molecular systematic investigation of the Limatula ovalis/pygmaea species complex (Bivalvia: Limidae) in the Southern Ocean. MSc Thesis, Imperial College, University of London, London, 77 pp. 
Page T \& K Linse. 2002. More evidence of speciation and dispersal across the Antarctic Polar Front through molecular systematics of Southern Ocean Limatula (Bivalvia: Limidae). Polar Biology 25: 818-826.

Paredes C, P Huamán, F Cardoso, R Vivar \& V Vera. 1999. Estado actual del conocimiento de los moluscos acuáticos en el Perú. Revista Peruana de Biologia 6: 5-47.

Ramírez R, C Paredes \& J Arenas. 2003. Moluscos del Perú. Revista de Biología Tropical 51(suppl 3): 225-284.

Ramorino L. 1968. Pelecypoda del fondo de la bahía de Valparaíso. Revista de Biología Marina 13: 175-286.

Ríos C, E Mutschke \& E Morrison. 2003. Biodiversidad bentónica sublitoral en el estrecho de Magallanes, Chile. Revista de Biología Marina y Oceanografía 38: 1-12.

Stuardo J. 1968. On the phylogeny, taxonomy and distribution of the Limidae (Mollusca: Bivalvia). PhD thesis, Harvard University, Cambridge, 327 pp.
Smith AE. 1907. The Lamellibranchiata, National Antarctic Expedition 1901-1904, Natural History 2: 1-7.

Thiele J. 1912. Die antarktischen Schnecken und Muscheln. Deutsche Südpolar-Expedition, 1901-1903, im Auftrage des Reichsamtes des Innern, herausgegeben von Erich von Drygalski 13: 183-285.

Zamorano P, ME Hendrick \& A Toledano-Granados. 2007. Distribution and ecology of deep-water mollusks from the continental slope, southeastern Gulf of California, Mexico. Marine Biology 150: 883-892.

Zuschin M \& W Piller. 1997. Bivalve distribution on coral carpets in the northern Bay of Safaga (Red Sea, Egypt) and its relation to environmental parameters. Facies 37: 183194.

Annex. Abbreviation in Figures 3-5 / Abreviaciones usadas en Figuras 3-5

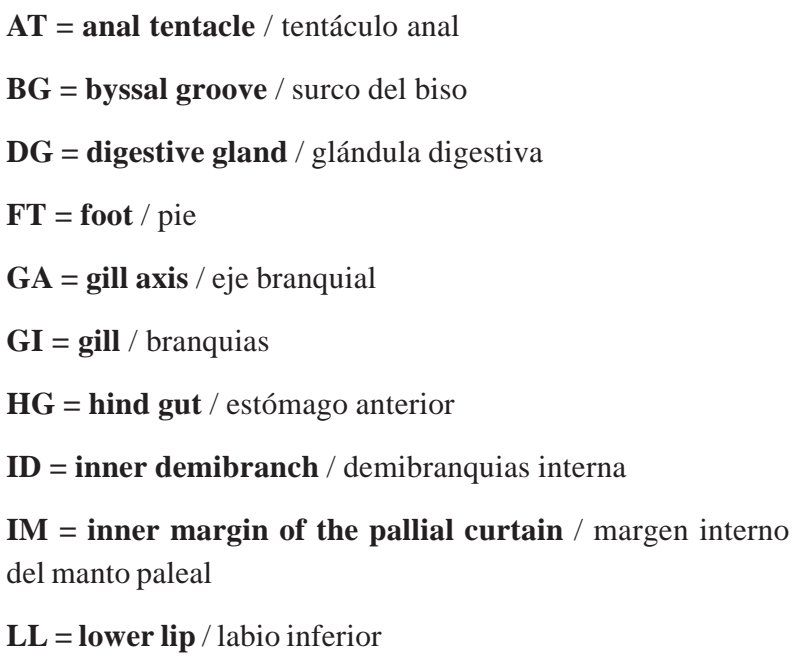

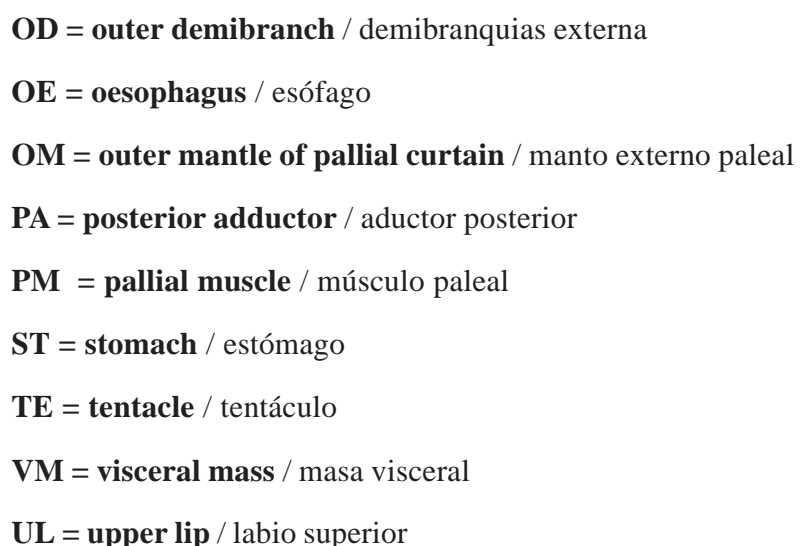

Received 10 February 2012 and accepted 3 June 2012

Associate Editor: Mauricio Landaeta D. 